\title{
Nutrition in oncology: The case of micronutrients (Review)
}

\author{
ALEXANDER STRÖHLE $^{1}$, KURT ZÄNKER ${ }^{2}$ and ANDREAS HAHN $^{1}$ \\ ${ }^{1}$ Nutrition Physiology and Human Nutrition Unit, Institute of Food Science, Leibniz University of Hannover, Hannover; \\ ${ }^{2}$ Institute of Immunology and Experimental Oncology, University of Witten/Herdecke, Witten, Germany
}

Received April 12, 2010; Accepted June 11, 2010

DOI: 10.3892/or_00000925

\begin{abstract}
In the course of cancer disease, many oncological patients develop tumor-associated malnutrition characterized by an insufficient supply of macro- and micronutrients. The inadequate nutritional status and the cancer anorexia-cachexia syndrome related to it are clinically relevant, as the response to antineoplastic measures, such as radiation and chemotherapy, is diminished, their side effects aggravated and the patient's quality of life and prognosis negatively affected. Therefore, the supportive nutrition care of oncological patients is of central importance. In this context, vitamins, minerals and long-chain $\omega-3$ fatty acids are becoming more and more relevant in oncology although the benefit of such supplements is discussed controversially. Starting from a description of the etiopathogenesis and the pathophysiological consequences of cancer-associated malnutrition, the present study provides an overview of the importance of micronutrients for oncological patients. In the case of reduced food intake and/or inappropriate food choice the use of a multi-vitaminmultimineral supplement administered in physiological doses, i.e. nutrient quantities approximately corresponding to the recommended daily allowances, can be generally recommended. However, to enhance postoperative wound healing, it seems that cancer patients require higher amounts of micronutrients than healthy individuals. Because vitamin D deficiency is highly prevalent in oncological patients, improvement of vitamin D status is of special interest.
\end{abstract}

\section{Contents}

1. Introduction

2. Tumor-associated malnutrition - etiopathogenesis and pathophysiological consequences

Correspondence to: Dr Alexander Ströhle, Nutrition Physiology and Human Nutrition Unit, Institute of Food Science, Am Kleinen Felde 30, Leibniz University of Hannover, Hannover, Germany E-mail: stroehle@nutrition.uni-hannover.de

Key words: cancer cachexia, malnutrition, vitamins, trace elements, $\omega-3$ fatty acids
3. Tumor-associated deficit of micronutrients pathophysiological consequences and therapeutic options with micronutrient supplements

4. Micronutrient supplementation in the supportive nutrition care of tumor patients - compensating a nutrient deficit

5. Micronutrient supplementation in the supportive nutrition care of tumor patients - influencing the disease symptoms

6. Summary and recommendations

\section{Introduction}

According to current estimates, about 11 million people develop malignant tumors worldwide every year. Among the most frequent cancer diseases are neoplasias of the lung, colon and rectum and, depending on the patient's gender, neoplasias of the prostate and mammary gland (1). Due to the age-depending cancer incidence and the ageing population, the number of new cancer cases is expected to double until the year 2030 (2). Both epidemiological and experimental-mechanistic studies confirm that eating habits and/ or individual nutrition factors fundamentally modify the risk of developing epithelial tumor diseases (3-7).

Whereas the benefit of a healthy eating strategy in the sense of 'chemoprevention' (8-11) has been established scientifically for some time $(6,7)$, additional measures of nutrition care also are of great significance for patients suffering from a manifest cancer disease (12-16). This is due to the fact that many cancer patients develop a tumor-associated malnutrition characterized by an insufficient supply of macro- and micronutrients (17-31). The inadequate nutrition status and the cancer anorexia-cachexia syndrome combined with it $(15,32-34)$ are clinically relevant because they not only diminish the response to antineoplastic measures, such as radiation and chemotherapy $(35,36)$, but also aggravate their side effects and have a negative impact on the patient's quality of life and prognosis (14,37-43). Thus, an adequate nutritional intervention can have a beneficial influence on the progress of the disease and the patient's condition. Against this background it is evident that a supportive nutrition therapy should be an integral part of cancer care (44-46). In addition to a sufficient supply of energy substrates, vitamins and minerals as well as long-chain $\omega-3$ fatty acids are becoming more and more interesting (31,47-56), although the therapeutic benefit of such supplements is the subject of a controversial discussion, especially in respect 
Table I. Frequency of malnutrition defined by a disease-related weight loss depending on tumor localization.

\begin{tabular}{lc}
\hline Type of tumor & Proportion of patients (\%) \\
\hline Pancreatic carcinoma & 83 \\
Gastric carcinoma & 83 \\
Esophageal carcinoma & 79 \\
Carcinomas of the head and neck & 72 \\
Colorectal carcinoma & $55-60$ \\
Pulmonary carcinoma & $50-66$ \\
Prostate carcinoma & 56 \\
Mammary carcinoma & $10-35$ \\
\hline
\end{tabular}

Source, Laviano and Meguid (68).

of supplements with high concentrations of antioxidants like the vitamins $\mathrm{C}$ and $\mathrm{E}$ and the trace element selenium (57-66).

Starting from a description of the etiopathogenesis and the pathophysiological consequences of cancer-associated malnutrition, the present study provide an overview of the relevance of micronutrients to oncological patients. Following van Ommen et al (67), the term of 'micronutrients' includes both vitamins and mineral substances as well as $\omega-3$ fatty acids.

\section{Tumor-associated malnutrition - etiopathogenesis and pathophysiological consequences}

Malnutrition, primarily characterized by a rapid weight loss, is a typical finding in patients suffering from cancer (19-26). Depending on the type and localization of the tumor and the stage of the disease, significant malnutrition is observed in $30-90 \%$ of the tumor patients, and many patients have nutrition deficits already before the therapy begins $(19,20,41)$. Malnutrition is particularly severe in patients with a tumor of the gastrointestinal tract (Table I).

Tumor-associated malnutrition is of multifactorial origin (Fig. 1, right side of the picture) and initially due to a reduced substrate and energy supply which has itself various causes related to the cancer disease. They include $(12,15)$ : i) neuropsychological-dysregulation of the hunger-satiation feeling characterized by the development of anorexia found in $15-40 \%$ of the tumor patients (69), for which, in addition to taste and smell abnormalities (70-73) and disease-related depressive symptoms (74), mainly the cytokine-mediated dysfunction of the hypothalamic neurochemistry is made responsible $(33,75-77)$. Thus, it is assumed that various cytokines, such as interleukin-6 (IL-6) and tumor-necrosis factor $\alpha$ $(\mathrm{TNF}-\alpha)$ which are secreted in large amounts by the tumor itself but, due to the tumor disease, also by the host organism, inhibit the neuropeptide Y (NPY) signal cascade in the lateral hypothalamus and increase the expression and release of proopiomelanocortin (POMC) in the diobasal hypothalamus. Both effects act as an anorectic signal and reduce the hunger feeling and therefore the food intake (33); ii) mechanical- disturbed food intake, e.g. due to tumors in the oral cavity and oesophagus (78); iii) physiological-impaired nutrient digestion and/or absorption due to tumors in the gastrointestinal tract (78); and iv) iatrogenic-disturbed nutrient utilization as a result of antineoplastic therapy, associated with a consecutive nutrient deficit. In general, the risk of malnutrition rises when antineoplastic procedures are initiated $(15,24,36)$. In particular radiation and chemotherapy, and to an ever larger extent the combined chemo-readiotherapy, is associated with a number of side effects (such as stomatitis, enteritis and mucositis) $(79,80)$ which, as a secondary effect, may affect the patient's food selection as well as nutrient absorption and nutrient utilization (24,81-83, Tables II and III).

Malnutrition is associated with and aggravated by a higher metabolic turnover rate observed in many cancer patients caused by certain substances released by the tumor itself, such as the tumor peptides proteolysis inducing factor (PIF) and lipid mobilizing factor (LMF), and the cytokines IL- 6 and TNF- $\alpha$ mentioned above. As anorexogenic mediators both classes of compounds lead to a number of changes in the intermediary macronutrient metabolism (Fig. 1, left side). They include among others $(33,88-92)$ : i) increase in whole body protein turn-over (93) with elevated protein catabolism combined with persistent degradation of muscle protein (94). At the molecular level, these changes are mainly induced by the proteolysis inducing factor (PIF), a sulphated glycoprotein which activates the enzyme phospholipase $A_{2}$ in the muscle cells leading to an increased release of arachidonic acid (AA) from the cell membranes. AA is then partly transformed into 15-hydroxyeicosatetraenic acid by 15-lipogenase. Hydroxyeicosatetraenic acid activates NADPH oxidase and thus the formation of reactive oxygen species (superoxide radicals; $\left({ }^{\circ} 2^{-}\right)$causing the upregulation of the inducible transcription factor $\mathrm{NF}-\kappa \mathrm{B}$ which induces the expression of the ubiquitin-proteasome system (95-98). This ATPdepending proteolysis complex contains, as an essential component, multicatalytic proteases which finally catalyze the hydrolytic protein degradation in the myocytes (for an overview of the ubiquitin-proteasome system see ref. 90); and ii) mobilization of peripheral fat and decrease of whole body lipid (99) as a result of increased lipolysis (100) and higher lipid oxidation (101). The lipid mobilizing factor (LMF) and zinc $\alpha$-glycoprotein (ZAG) could be identified as the principal mediators of these changes. Both activate the hormone-sensitive lipase via the cAMP pathway and thus the hydrolytic release of fatty acids from the adipocytes $(102,103)$.

In combination with the reduced nutrient intake and/or absorption mentioned above, the catabolic changes in the metabolism finally lead to the development of cancer cachexia characterized by a drastic weight loss-especially loss of substantial body mass ('wasting'), and systemic inflammation (104). The latter is associated with an increased formation of reactive oxygen species (ROS) which could be detected in cancer patients (53).

Tumor-associated malnutrition and the tumor cachexia related to it not only diminish the response to antineoplastic therapy $(35,36)$ and aggravate the side effects of tumor therapy $(35,36,108,110)$, but also affect the patient's quality of life (14), a fact of clinical relevance. Especially the finding that 


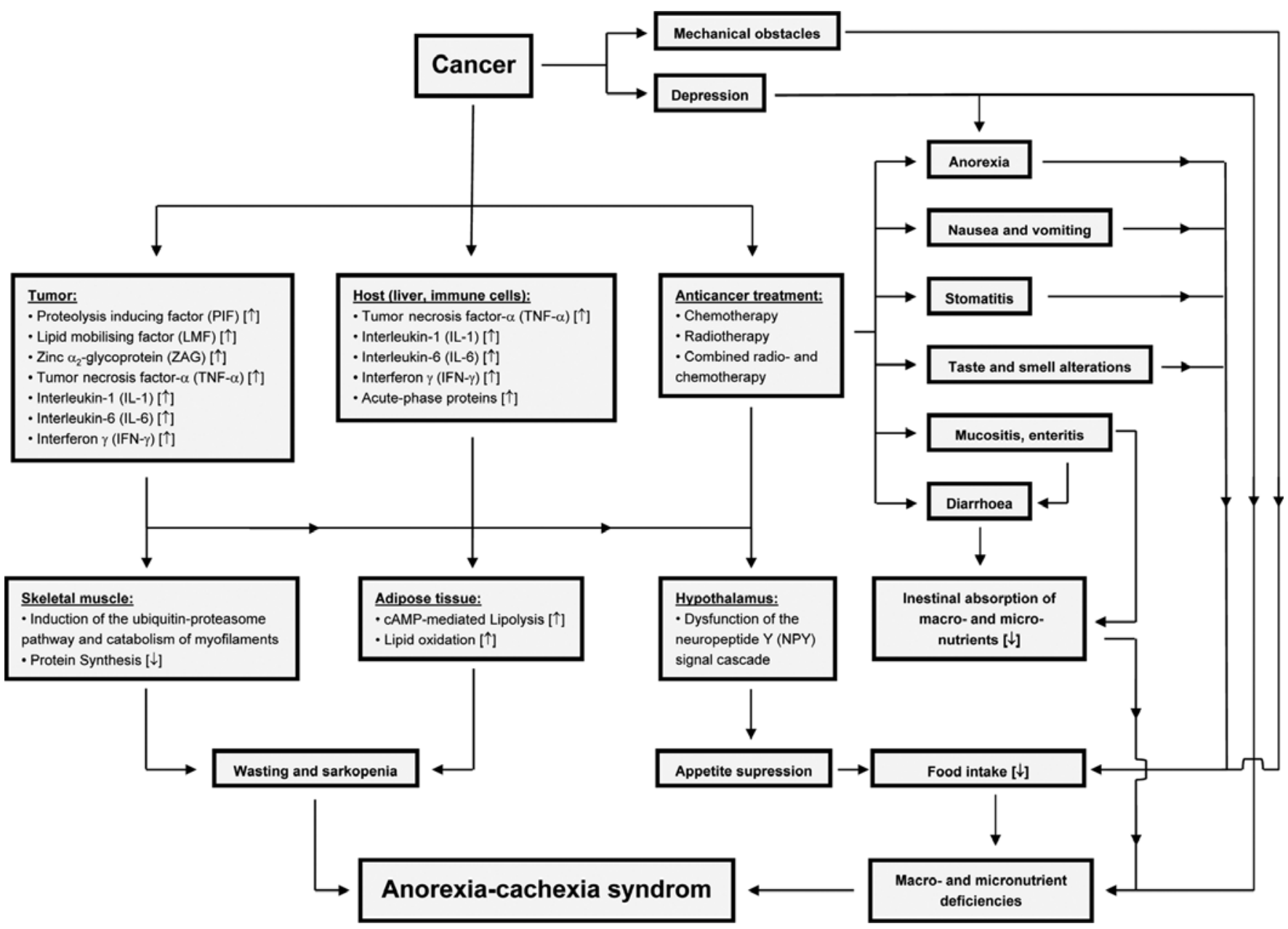

Figure 1. Multifactorial genesis of tumor-associated malnutrition and cachexia (based on the sources of refs. 15,34,89,105-107).

malnourished cancer patients have an elevated morbidity and mortality risk is clinically relevant $(41,42,111-118)$. Besides sepsis, tumor cachexia still is the most frequent cause of death of cancer patients (13).

\section{Tumor-associated deficit of micronutrients - patho- physiological consequences and therapeutic options with micronutrient supplements}

As Fig. 1 shows, the malnutrition of many cancer patients is not limited to macronutrients, but the supply of various vitamins and minerals also is often inadequate. In general, a deficient micronutrient supply can be assumed for all cancer patients whose energy uptake amounts to $<60 \%$ of the daily requirements for more than 10 days and who, according to the ESPEN Guidelines, must be considered inadequately supplied with food (13). This especially applies if, under chemo and radiation therapy, they rapidly lose, i.e. use up, micronutrients due to vomiting and diarrhea (84).

In fact, the status of vitamins C (119-121), D (122-124) and $\mathrm{E}$ (125) and of some B vitamins (126-128) is significantly lowered in many tumor patients compared with healthy individuals and/or the defined cut-off values found in the literature. For example, the vitamin C plasma levels found in some cancer patients are so low that they suffer from scurvy-like symptoms $(129,130)$. Also a significantly decreased concentration of the trace elements selenium and zinc was found in the serum of cancer patients $(31,51,131,132)$, and cases of severe deficiency symptoms (133) were described. The insufficient supply of antioxidant micronutrients of many cancer patients can also be seen in the fact that their oxidative stress markers are often increased $(120,134-136)$. The problem is aggravated by the falling vitamins A (137) and E (137,138-140) blood levels under radiation therapy.

Such a micronutrient deficit caused by the cancer disease is of importance in many respects: first, it compromises wound healing, so that there is a higher risk of complications after surgical interventions $(141,142)$. Secondly, a less than optimum supply of micronutrients, especially of some B vitamins, is associated with a higher risk of depressive symptoms $(143,144)$. Thirdly, even a moderate micronutrient deficit will compromise the immune competence of the organism $(145,146)$, as immune cells, due to their high proliferation rate, have an increased nutrient need. Therefore, the inadequate supply of vitamins and minerals has a negative effect on the immune defense of cancer patients. In this context, especially the trace elements zinc and selenium 
Table II. Diet-related side effects of chemotherapy.

\begin{tabular}{|c|c|c|}
\hline Adverse effects & Precipitating cancer treatments & Nutrition effects \\
\hline Nausea and vomiting & Most chemotherapy agents & Can significantly reduce food intake and cause dehydration \\
\hline $\begin{array}{l}\text { Mucositis (in the upper } \\
\text { gastrointestinal tract: } \\
\text { gingivitis, pharyngitis } \\
\text { and oesophagitis) }\end{array}$ & Antimetabolites, cytotoxic antibiotics & $\begin{array}{l}\text { Inflammation of mucosal epithelium cells of the gastro- } \\
\text { intestinal tract }\end{array}$ \\
\hline Diarrhea & $\begin{array}{l}\text { 5-Fluorouracil (5-FU), irinotecan, } \\
\text { hydroxyurea, methotrexate (MTX), } \\
\text { dactinomycin }\end{array}$ & $\begin{array}{l}\text { Intestinal loss of vitamins and electrolytes, disturbances of the } \\
\text { acid-base-homeostasis }\end{array}$ \\
\hline Stomatitis & $\begin{array}{l}\text { Bleomycin, dactinomycin, } \\
\text { doxorubicin (DOX), 5-fluorouracil } \\
\text { (5-FU), methotrexate (MTX) }\end{array}$ & $\begin{array}{l}\text { Sore mouth can significantly affect food intake/cause food } \\
\text { aversions }\end{array}$ \\
\hline Taste and smell alterations & $\begin{array}{l}\text { Carboplatin (CBP), cisplatin, cyclo- } \\
\text { phosphamide, doxorubicin (DOX), } \\
5 \text {-fluorouracil (5-FU), methotrexate } \\
\text { (MTX) }\end{array}$ & $\begin{array}{l}\text { Reports of food tasting metallic, like cardboard or sandpaper, } \\
\text { too salty, sweet, sour, or bitter, or having no taste }\end{array}$ \\
\hline
\end{tabular}

Modified according to Grant and Kravits (84) including O'Brien et al (85) and Naidu et al (86).

and vitamins $\mathrm{E}$ and $\mathrm{C}$ are of relevance. Table IV provides an overview of the immunobiological significance of selected vitamins and trace elements (following 146) $\downarrow$, reduced; $(\downarrow)$ possibly reduced; $\uparrow$ increased; $(\uparrow)$, possibly increased; $\rightarrow$, no effect; n.d., no data; C, controversial findings.

Against this background it is clearly evident that measures of nutrition medicine for cancer patients are important and necessary. Besides an adequate intake of energy-building substrates, an optimum supply of micronutrients is also required $(27-30,147)$. Therefore, in recent years the administration of micronutrient supplements to cancer patients has gained growing interest $(31,47-51,53,54,56)$. From the dietetic-therapeutic point of view, such substances can perform the following functions (148): i) compensation of a nutrient deficit induced by the cancer disease itself and/ or the antineoplastic therapy with the aim of improving the patient's nutritional status; and ii) specific supplementation for dietetic-therapeutic purposes aiming less at the supply of nutrients, rather at taking a beneficial influence on the course of the disease.

\section{Micronutrient supplementation in the supportive nut- rition care of tumor patients - compensating a nutrient deficit}

As explained in Section 3, many cancer patients have a multiple nutrient deficit. The risk of a less than optimum supply is particularly high if the food intake (based on the energy supply) amounts to $<60 \%$ of the required level over an extended period ( $>10$ days). In such cases it is often impossible to meet the nutrient requirements, not to mention the replenishment of empty nutrient storage sites of cancer patients just by the usual diet. The problem is made more difficult by the restricted dietary patterns of many cancer patients due to their food aversion $(73,78,149)$. Therefore, using micronutrient supplements can make sense in these cases $(147,150)$. Clinical studies have actually shown that the nutritional status of tumor patients can be improved by giving them vitamins and mineral substances $(31,51)$.

The question for the dose of vitamins and minerals that is useful and safe from the nutrition physiology point of view is more difficult to answer. As the degree of malnutrition (19), and thus the micronutrient deficit, differs in cancer patients depending on the tumor localization, the tumor stage and the type of antineoplastic therapy, the amount of micronutrients needed for dietetic care will have to vary from case to case. In general, for enteral feeding of all tumor patients a daily uptake amounting to the respective Recommended Dietary Allowances (RDA) (13) is recommended, an advice that can also be made with regard to the corresponding multivitaminmultimineral supplements $(59,147)$.

Referring to their antioxidant compound content (vitamins $\mathrm{C}, \mathrm{E}$ and selenium), the question whether supplying such substances during chemo and/or radiation therapy can be considered safe $(58,59,62,64-66)$, has repeatedly been the subject of a controversial discussion. Micronutrients with an antioxidant effect actually have the potential for capturing reactive oxygen species (ROS). In tumor biology this is sometimes considered a problem, as the tumor-destroying effect of chemo or radiation therapy is partly due to an increased formation of $\operatorname{ROS}(151,152)$. It is therefore possible that the adjuvant administration of antioxidants during chemo and radiation therapy will weaken the therapeutic effect and thus worsen the tumor patient's prognosis. 
Table III. Diet-related side effects of radiation therapy.

\begin{tabular}{|c|c|c|}
\hline Radiated body region & Acute effects & Late effects \\
\hline Central nervous system & $\begin{array}{l}\text { Nausea } \\
\text { Vomiting }\end{array}$ & \\
\hline Otolaryngological region & $\begin{array}{l}\text { Swallowing disorders } \\
\text { Dry mouth } \\
\text { Mucositis } \\
\text { Anorexia } \\
\text { Taste and smell alterations }\end{array}$ & $\begin{array}{l}\text { Ulcer } \\
\text { Dry mouth } \\
\text { Bone necrosis } \\
\text { Caries/sensitive tooth necks } \\
\text { Reduced/lacking sense of taste }\end{array}$ \\
\hline Thorax (lung, mediastinium, oesophagus) & $\begin{array}{l}\text { Swallowing disorders } \\
\text { Inappetence } \\
\text { Nausea }\end{array}$ & $\begin{array}{l}\text { Esophageal fibrosis } \\
\text { Esophageal stenosis } \\
\text { Esophageal perforation } \\
\text { Esophageal fistula }\end{array}$ \\
\hline Abdomen and pelvis & $\begin{array}{l}\text { Anorexia } \\
\text { Nausea } \\
\text { Vomiting } \\
\text { Diarrhea } \\
\text { Acute enteritis } \\
\text { Acute colitis } \\
\text { Acute proctitis } \\
\text { Sphincter insufficiency } \\
\text { Acute cystitis }\end{array}$ & $\begin{array}{l}\text { Ulcer } \\
\text { Diarrhea/malabsorption } \\
\text { Bleeding } \\
\text { Chronic enteritis/colitis } \\
\text { Stricture/obstruction } \\
\text { Fistula/perforation } \\
\text { Ureter stenosis } \\
\text { Renal failure }\end{array}$ \\
\hline
\end{tabular}

Modified according to 87.

In addition to cell culture studies and animal experiments, interventional studies were made with tumor patients based on these considerations with the aim of finding an answer to the question whether antioxidant supplementation would actually have a negative impact on the effectiveness of chemo or radiation therapy. Meanwhile a large number of survey studies (60-66,153-159) have been published, some of a systematic nature $(56,57)$, summarizing and evaluating the findings. In this context, two contradictory positions have developed expressed by two different views (147) maintaining that the administration of antioxidant supplements (in higher doses) as an adjuvant to chemo and/or radiation therapy: i) is not associated with any negative effects on the tumordestroying therapy; and ii) is associated with a weakening of the tumor-destroying therapy.

Thus, the adjuvant supply during chemo and radiation therapy is recommended $(60,64)$ on the one hand, and there is the opposite opinion warning against such a measure $(65,66)$ on the other. These divergent views can be explained, among other things, by the fact that the influence of an antioxidant supplementation on the effect of chemo or radiation therapy seems to depend on a number of factors (147): i) degree to which radicals are formed by the chemotherapeutic agent and in how far the chemotherapeutic effect depends on the potential formation of free radicals; ii) type of reactive oxygen compounds formed by the chemotherapeutic agent; iii) dose of the chemotherapeutic agent and concentration of the active oxygen species; iv) type of antioxidant; v) dose of antioxidant; and vi) time between application of the antioxidant and chemotherapy.

After evaluating the available data on the effect of antioxidant supplementation during chemo or radiation therapy, the American Institute for Cancer Research (AICR) arrives at the conclusion that patients under chemo or radiation therapy should abstain from taking vitamins or mineral substances containing more antioxidants in the daily amount than corresponds to the Upper Limits of Safe Intake (vitamin C, $2000 \mathrm{mg} /$ day, vitamin E, $250 \mathrm{mg}$ /day tocopherol equivalents, and selenium $400 \mu \mathrm{g} /$ day) (160). In general, says the AICR, taking dietary supplements during chemo or radiation therapy is to be considered safe as long as such supplements contain amounts of vitamins and mineral substances that are in the range of the recommended daily allowance according to the RDA recommendations (59).

\section{Micronutrient supplementation in the supportive nutrition care of tumor patients - influencing the disease symptoms}

Besides aiming at compensating the micronutrient deficit caused by the tumor disease, such supplements can also be given in order to influence the course of the disease in a 
Table IV. Immunological significance of selected vitamins and trace elements adapted from Ströhle and Hahn (146).

\begin{tabular}{ll}
\hline Micronutrient & Biochemical function \\
\hline Vitamin A & - As retinoids it regulates transcription \\
& of various genes whose corresponding \\
& proteins are involved in the control of \\
& cell growth and cell differentiation \\
& - As retinyl ester, carrier of mannose and \\
& involved in glycoprotein synthesis
\end{tabular}

Vitamin E

- Antioxidant defense

- Signal transduction

Vitamin $\mathrm{B}_{6} \quad$ - Coenzyme in porphyrin and amino acid $\quad$ Essential factor for antibody and metabolism, involved in nucleic acid and protein synthesis

- Modulates effect of steroid hormones
Immunological function

Effect on immune competence

- Essential factor for the integrity of skin Deficiency:

and mucous membranes that act as antigen barrier

- Essential for humoral and cellular immune response

- Reduces immune suppressive effect of free radicals in respiratory burst

- Modulation of eicosanoid formation via inhbition of cyclooxigenase and lipid oxygenase with resulting antiinflammatory activity

- Essential for humoral and cellular immune response

\section{cytokine synthesis}

- Weakening the skin-mucosa barrier and increasing infection risk

- Proliferation and cytotoxicity of T-lymphocytes $\downarrow$

- Antigen-specific response $\downarrow$

- Proinflammatory effect (TNF- $\alpha$ synthesis $\uparrow$ )

- Change in TH1:TH2 ratio in favor of TH1

Supplementation

(physiological doses)

- Phagocytosis $\uparrow$

- Synthesis of interferon- $\gamma$, TNF- $\alpha \downarrow$

- Antibody formation $\uparrow$

Supplementation

(non-physiological doses)

- Antigen-specific response $\downarrow$

Deficiency

- Antigen-specific response $\downarrow$

- Proliferation and cytotoxicity of T-lymphocytes $\downarrow$

- Phagocytosis $\downarrow$

Supplementation

(physiological doses)

- T-cell proliferation $\uparrow$

- Favorable effect on $\mathrm{CD}^{+}: \mathrm{CD} 8^{+}$ quotient

- Oxidative stress $\downarrow$

- Th1 activity $\uparrow$

Supplementation

(non-physiological doses)

- Antigen-specific response $\downarrow$

Deficiency

- Lymphocyte maturation and proliferation $\downarrow$

- T-lymphocyte activity $\downarrow$

- Antibody formation $\downarrow$

- Interleukin-2 synthesis of T-helper cells $\downarrow$

Supplementation

(physiological doses)

- Lymphocyte proliferation $\uparrow$

- Interleukin-2 synthesis of T-helper cells $\downarrow$ 
Table IV. Continued.

\begin{tabular}{|c|c|c|c|}
\hline Micronutrient & Biochemical function & Immunological function & Effect on immune competence \\
\hline olic acid & $\begin{array}{l}\text { - Coenzyme in the metabolism of amino } \\
\text { acids, purins, pyrimidines and cholin; thus } \\
\text { involved in the nucleic acid and protein } \\
\text { synthesis } \\
\text { - Epigenetic modification of DNA via } \\
\text { methylation }\end{array}$ & $\begin{array}{l}\text { - Essential factor for the growth of } \\
\text { rapidly proliferating immune } \\
\text { cells } \\
\text { - Essential factor for antibody and } \\
\text { cytokine synthesis }\end{array}$ & $\begin{array}{l}\text { Deficiency: } \\
\text { - Thymus weight } \downarrow \\
\text { - Neutrophil activity } \downarrow \\
\text { - Cytotoxicity of T-lymphocytes } \downarrow \\
\text { - Antibody formation } \downarrow \\
\text { - Lymphocyte proliferation } \downarrow \\
\text { - Activity of natural killer cells } \downarrow \\
\text { Supplementation } \\
\text { (physiological doses): } \\
\text { - Lymphocyte proliferation } \uparrow \\
\text { - Cytotoxicity of natural killer cells } \uparrow\end{array}$ \\
\hline Vitamin $B_{12}$ & $\begin{array}{l}\text { - Coenzyme in the metabolism of homo- } \\
\text { cystein, odd-numbered fatty acids and } \\
\text { branched-chain amino acids }\end{array}$ & $\begin{array}{l}\text { - Closely related to folic acid } \\
\text { metabolism, essential for the } \\
\text { growth of immune cells and } \\
\text { antibody and cytokine synthesis }\end{array}$ & $\begin{array}{l}\text { Deficiency: } \\
\text { •Neutrophil activity } \downarrow \\
\text { - Activity of natural killer cells } \downarrow\end{array}$ \\
\hline Iron & $\begin{array}{l}\text { - As a component of hemoglobin and myo- } \\
\text { globin involved in erythrocytic oxygen } \\
\text { transport and oxygen storage in the muscles } \\
\text { - Component of metalloenzymes, e.g. dioxy- } \\
\text { genases and monooxygenases, involved in } \\
\text { eicosanoid, carnitine, collagen and neuro- } \\
\text { transmitter synthesis } \\
\text { - Component of hemenzymes, e.g. guanylate } \\
\text { cyclase, NO-synthase, peroxidase and } \\
\text { catalase, involved in signal transduction } \\
\text { and antioxidant defense }\end{array}$ & $\begin{array}{l}\text { - Essential factor for maturation, } \\
\text { differentiation and proliferation } \\
\text { of lymphocytes } \\
\text { - Essential factor for cytokine } \\
\text { synthesis } \\
\text { - As a component of NADPH oxi- } \\
\text { reductase and myeloperoxidase } \\
\text { involved in the formation of anti- } \\
\text { microbial hypochloride }\end{array}$ & $\begin{array}{l}\text { Deficiency: } \\
\text { - Secretion of interferon- } \gamma, \text { TNF- } \alpha \\
\text { and interleukin } 2 \downarrow \\
\text { - Activity of natural killer cells } \downarrow \\
\text { - T-cell proliferation } \downarrow \\
\text { - Bactericidal activity of macrophages } \downarrow\end{array}$ \\
\hline Zinc & $\begin{array}{l}\text { - Integral component, i.e. effector, of over } \\
150 \text { enzymes of all } 6 \text { enzyme classes, } \\
\text { involved in carbohydrate, lipid, amino } \\
\text { acid and nucleic acid metabolism } \\
\text { - Site-specific antioxidant } \\
\text { - Component of transcription factors, } \\
\text { regulates gene expression }\end{array}$ & $\begin{array}{l}\text { - Essential factor of thymulin } \\
\text { synthesis, needed for T-cell } \\
\text { activity (cytotoxicity, etc.) } \\
\text { • Essential factor for cytokine } \\
\text { synthesis } \\
\text { - Essential factor for the growth of } \\
\text { all rapidly proliferating immune } \\
\text { cells } \\
\text { - Protects immune cells against } \\
\text { oxidative damage } \\
\text { - Essential factor for the integrity } \\
\text { of skin and mucous membranes } \\
\text { acting as antigen barrier }\end{array}$ & $\begin{array}{l}\text { Deficiency: } \\
\text { - Interferon- } \gamma \text { and interleukin } 2 \\
\text { synthesis } \downarrow \\
\text { - Activity of natural killer cells } \downarrow \\
\text { - Macrophage activity } \downarrow \text { (phagocytosis } \downarrow \text {; } \\
\text { bactericidal effect } \downarrow \text {, chemotaxis } \downarrow \text { ) } \\
\text { - T-cell activity } \downarrow \\
\text { - Thymus atrophy } \\
\text { Supplementation } \\
\text { (physiological doses): } \\
\text { - Phagocytosis } \uparrow \\
\text { - Activity of natural killer cells } \uparrow \\
\text { - Antibody formation } \uparrow \\
\text { Supplementation } \\
\text { (non-physiological doses) } \\
\text { - Lymphocyte proliferation } \uparrow \\
\text { - Interferon- } \gamma \text { synthesis } \downarrow \text { T-cell activity } \downarrow\end{array}$ \\
\hline Selenium & $\begin{array}{l}\text { - Component of glutathion peroxidase, } \\
\text { involved in the degradation of peroxides, } \\
\text { e.g. hydrogen peroxide }\end{array}$ & $\begin{array}{l}\text { - Essential factor for lymphocyte } \\
\text { activity }\end{array}$ & $\begin{array}{l}\text { Deficiency: } \\
\text { - Proinflammatory eicosanoid synthesis } \uparrow \\
\text { - Antibody formation } \downarrow\end{array}$ \\
\hline
\end{tabular}


Table IV. Continued.

\begin{tabular}{|c|c|c|c|}
\hline Micronutrient & Biochemical function & Immunological function & Effect on immune competence \\
\hline Selenium & $\begin{array}{l}\text { - Component of deiodases, involved in the } \\
\text { transformation of thyroxine (T4) to } \\
\text { triiodine thyronine } \\
\text { - Component of thioreductases, involved in } \\
\text { the redox metabolism }\end{array}$ & $\begin{array}{l}\text { - Protects immune cells against } \\
\text { oxidative damage }\end{array}$ & $\begin{array}{l}\text { Supplementation } \\
\text { (physiological doses): } \\
\text { - Interferon- } \gamma \text { synthesis } \\
\text { - Th1 response } \uparrow \\
\text { - T-lymphocyte proliferation } \uparrow \\
\text { - Cytotoxicity of natural killer cells } \uparrow\end{array}$ \\
\hline
\end{tabular}

beneficial way: i) to support wound healing; ii) to counteract tumor cachexia; and iii) in the longer term to improve the patient's quality of life and prognosis.

Supporting wound healing. Among the multiple ways of treating tumors, surgical procedures play an important role, both as a primary measure and after neoadjuvant, volumereducing chemo or radiation therapy. Rapid wound healing of the surgical site free of complications is often crucial to the success of any subsequent therapy. Disturbed wound healing and resulting infections not only impair the patient's quality of life but also delay further therapeutic measures $(141,142)$.

Both wound closure and tissue regeneration are processes that depend on an adequate supply of micronutrients. Vitamins $\mathrm{A}, \mathrm{C}, \mathrm{E}$ and $\mathrm{B}_{6}$ in particular, but also the trace elements zinc, manganese and copper, as enzyme cofactors, are involved in biochemical-physiological processes that are directly related to would healing (Table V).

One micronutrient that is given great attention both experimentally and clinically is vitamin $\mathrm{C}$ (ascorbic acid). As an essential cofactor for the dioxygenases prolyl 4-, prolyl 3 - and lysyl hydroxylase, ascorbic acid is relevant to the structure and function of collagen, as the ascorbate dependent dioxygenases cause the cotranslational hydroxylation of proline and lysine residues in the procollagen $(165,166)$. Although it has been known for a long time that the postoperative need for vitamin $C$ is higher than normal $(167,168)$, the question for the optimum vitamin $\mathrm{C}$ supply for wound healing in humans has so far not been definitely answered. Based on the results of an interventional study made by Taylor et al (169), a vitamin C supply of $1000 \mathrm{mg} /$ day can be recommended to post-surgical patients (164), an amount that is also recommended for the optimization of wound healing (163). For the other micronutrients shown in Table V there are no reliable data from studies in humans so that the recommended doses mentioned for them can only be considered approximate values.

The pronounced synergy effects of the individual micronutrients are of clinical relevance. They help us understand why the use of single highly dosed substances often remains ineffective whereas nutrient combinations of multiple composition can produce clinically relevant effects (164).

Controlling cachexia. Starting from the recognition that various anorexogenic mediators, such as PIF, cytokines (e.g. IL-6 and TNF- $\alpha$ ) and ROS, are central to the genesis of tumor cachexia, micronutrient supplements offer nutritional care two basic approaches. They include the administration of: i) antioxidants (vitamins $\mathrm{C}$ and $\mathrm{E}, \mathrm{N}$-acetylcystein, $\alpha$-liponic acid) (54-56,170-172); and ii) fish oils (173-175).

Whereas the findings on the anticachectic effects of an antioxidant therapy are still in the experimental stage for the most part, and therefore not dealt with any further in this study, there are abundant preclinical and clinical data on the subject of 'fish oils and tumor cachexia' The fish oil components relevant in this context are the long-chain $\omega$-3 fatty acids eicosapentaenic acid (EPA, C20:5 $\omega$-3) and docosahexaenic acid (DHA, C22:6w-3). Humans are capable of synthesising both fatty acids from $\alpha$-linolenic acid (ALA, $\mathrm{C} 18: 3 \omega-3)$ in a multistage conversion process, which primarily takes place in the endoplasmic reticulum of liver cells (176). However, the synthesis of EPA and DHA from ALA is extremely slow and low yielding (177). It is estimated that an intake of approximately $20 \mathrm{~g}$ pure ALA is necessary to obtain $1 \mathrm{~g}$ EPA (178). The synthesis of DHA in humans appears to be more complicated than was long thought, since it is clear that another pathway also exists (179). According to the alternative pathway, docosapentanoic acid (C22:5 $\omega-3)$

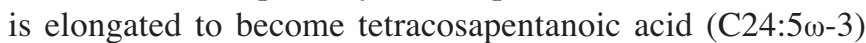
followed by a $\Delta 6$ desaturation. The next reaction step occurs after transfer of the fatty acid to peroxisomes, where a specific ß-oxidation shortens the chain to a $\mathrm{C} 22$ product. The complexity of this conversion may be another reason for its ineffectiveness.

With respect to cancer cachexia, EPA display mainly two direct biochemical effects: inhibition of the TNF- $\alpha$ and the PIF signalling pathway, whereby in both cases the inhibition of the NF- $\mathrm{KB}$ system, and thus finally the downregulation of 
Table V. Significance of selected micronutrients for wound healing (compiled according to 161-164).

\begin{tabular}{|c|c|c|c|}
\hline Micronutrient & Biochemical function & $\begin{array}{l}\text { Physiological function for } \\
\text { wound healing }\end{array}$ & $\begin{array}{l}\text { Recommended } \\
\text { daily dose }\end{array}$ \\
\hline $\begin{array}{l}\text { Vitamin C } \\
\text { (ascorbic acid) }\end{array}$ & $\begin{array}{l}\text { Cofactor of prolyl-3/prolyl- } 4 \text { oxidase } \\
\text { and lysyl hydroxylase (prolyl- } 6 \text { oxidase) }\end{array}$ & $\begin{array}{l}\text { Essential for postranslational hydroxylation } \\
\text { of procollagen and thus for the synthesis } \\
\text { of collagen and its interlinkage in the } \\
\text { connective tissue }\end{array}$ & $500-2000 \mathrm{mg}^{\mathrm{a}}$ \\
\hline Vitamin A & $\begin{array}{l}\text { Retinoids: } \\
\text { Element of transcription factor, } \\
\text { regulation of gene expression and } \\
\text { synthesis of proteins involved in the } \\
\text { control of cell growth and cell } \\
\text { differentiation } \\
\text { Retinyl ester: } \\
\text { Carrier of mannose, involved in glyco- } \\
\text { protein synthesis }\end{array}$ & Essential for epithelial-dermal integrity & $10000 \mathrm{IU}^{\mathrm{b}}$ \\
\hline $\begin{array}{l}\text { Vitamin } \mathrm{B}_{6} \\
\text { (pyridoxine) }\end{array}$ & $\begin{array}{l}\text { Pyridoxal phosphate }(P A L P) \text { : } \\
\text { Cofactor of amino transferases }\end{array}$ & $\begin{array}{l}\text { Essential for connective tissue protein } \\
\text { synthesis }\end{array}$ & $10-15 \mathrm{mg}^{\mathrm{a}}$ \\
\hline Folic acid & $\begin{array}{l}\text { Tetrahydrofolate (THF): } \\
\text { Cofactor of C-1 metabolism (transfer of } \\
\text { methyl, methylene and formyl residues), } \\
\text { involved in amino acid, purine and } \\
\text { pyrimidine synthesis }\end{array}$ & $\begin{array}{l}\text { Essential for connective tissue protein } \\
\text { synthesis }\end{array}$ & $0.4-1.0 \mathrm{mg}^{\mathrm{a}}$ \\
\hline Zinc & $\begin{array}{l}\text { Cofactor of prolyl- } 4 \text { oxidase and matrix- } \\
\text { metalloproteases }\end{array}$ & $\begin{array}{l}\text { Essential for postranslational procollagen } \\
\text { hydroxylation, and thus for synthesis } \\
\text { of collagen and its crosslinking in } \\
\text { connective tissues } \\
\text { Essential for keratocyte migration into the } \\
\text { wound area }\end{array}$ & $\begin{array}{c}4-10 \mathrm{mg}^{\mathrm{a}} \\
\text { (in case } \\
\text { of low initial } \\
\text { plasma values) }\end{array}$ \\
\hline Copper & $\begin{array}{l}\text { Cofactor of prolyl-6 oxidase (lysyl } \\
\text { hydroxylase); inducer of endothelial } \\
\text { growth factor (EGF) }\end{array}$ & $\begin{array}{l}\text { Essential for postranslational procollagen } \\
\text { hydroxylation, and thus for synthesis } \\
\text { of collagen and its crosslinking in } \\
\text { connective tissues } \\
\text { Essential for angiogenesis in the wound area }\end{array}$ & $1-2 \mathrm{mg}^{\mathrm{a}}$ \\
\hline
\end{tabular}

according to data of Demling (163); baccording to data of Kurmann and Burrowes (164).

the ubiquitin-proteasome system, seems to play a key role (96-98,180,181) (Fig. 2).

Based on animal experiments which confirm the anticachectic effects of an $\omega-3$ fatty acid supplementation, a number of prospective observational and interventional studies with cancer patients have meanwhile been made and evaluated $(173,174)$. A review of 17 such studies by Colomer et al (173) led to the following results: i) enteral supplements containing long-chain $\omega-3$ fatty acids are of benefit (increased weight and appetite) in patients with advanced cancer and weight loss, and are recommended in patients with tumors of the upper digestive tract and pancreas; ii) the recom- mended dose is 1.5-2.0 g per day long-chain $\omega$-3 fatty acids (EPA); and iii) there is low incidence of adverse side effects, so there is no limitation with respect to duration of supplementation.

Quality of life and prognosis. The relevance of micronutrients as part of the supportive nutritional care of cancer patients is confirmed not least by the results of studies showing that the intake of micronutrient supplements can improve both the quality of life and the prognosis of tumor patients (38-40). Thus, in an observational study with lung cancer patients the risk of dying was $20 \%$ lower in the patients 


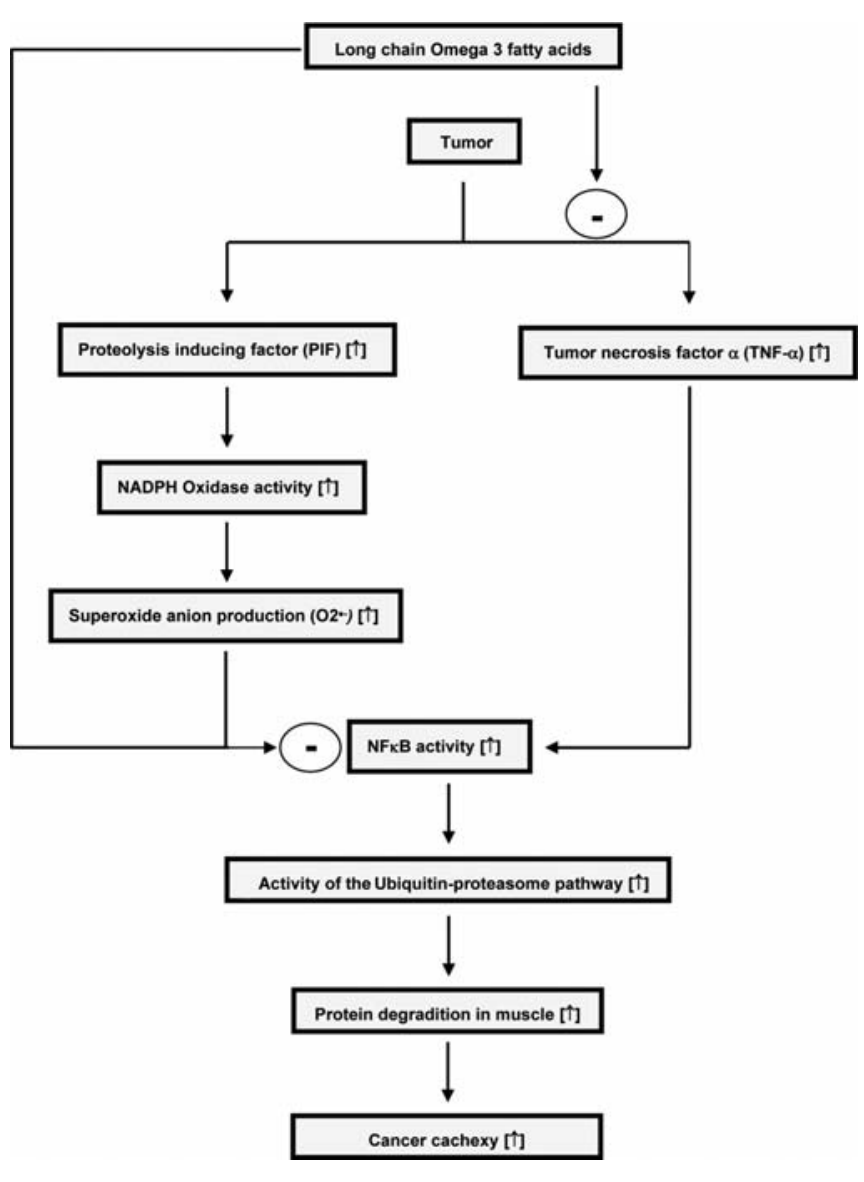

Figure 2. Anticachectic effect of long-chain $\omega$-3 fatty acids. '-', downregulate).

using supplements vs. those not using supplements $(95 \%$ confidence interval $(\mathrm{CI}): 0.44,0.65 ; \mathrm{p}<0.01)$. The mean survival time of the patients taking micronutrient supplements was 4.3 years, whereas it was only 2 years for the patients who did not take any. Moreover, in this study using a micronutrient supplement was associated with an improvement in the quality of life (Lung Cancer Symptom Scale) (mean difference in score of $3(95 \% \mathrm{CI}: 0.8,5.1 ; \mathrm{p}<0.01)$; and after adjusting for related variables, there remained a trend in favor of vitamin/mineral use mean difference $1.8(95 \%$ CI: $0.2,3.9 ; p=0.08)(39)$. In this context, the result of a randomized, unblinded, clinical trial with long-chain $\omega-3$ fatty acids is of relevance which when giving the patients fish oil demonstrated a significantly $(\mathrm{p}<0.001)$ longer survival time of patients with generalized solid tumors (47). There also are first indications showing that $\omega-3$ fatty acids may improve the cellular absorption of various chemotherapeutic agents and thus support the effectiveness of antineoplastic therapy (50). In addition, the results of current prospective observational studies indicate that the subject of 'vitamin D supply and prognosis of tumor patients' may become more important in the field of oncology in the future. For instance, the plasma level of 25-hydroxyvitamin $\mathrm{D}_{3}$ proved to be an independent predictor for the survival of patients with breast cancer (182) and patients with colorectal carcinoma $(183,184)$. In view of the data on the vitamin $\mathrm{D}$ deficit of tumor patients (122-124) presented in Section 3, these finding deserve special attention.

\section{Summary and recommendations}

In the course or their disease, many cancer patients develop tumor-associated malnutrition which, among other things, is characterized by a micronutrient deficit. In practice, it is not always possible in such special circumstances to counteract this condition in an optimum way by the diet, i.e. the conventional food selection. Often the situation is made more difficult by the limited dietary pattern of tumor patients which may lead to a very one-sided nutrition. Therefore, it is not surprising that the use of nutrient supplements, among them especially vitamins and mineral substances, is widespread among cancer patients $(185,186)$. However, the interest in micronutrient supplements is not restricted to the group of users. On the contrary, the use of vitamins, mineral substances and long-chain $\omega-3$ fatty acids is also gaining a growing, though controversial, interest in oncology (51-66).

Based on the above, our findings can be summarized for practical purposes in the following way: i) in view of the restricted dietary pattern of tumor patients, the use of a multivitamin-multimineral supplement in physiological doses, i.e. nutrient amounts that approximately equal the recommended daily allowance, is a useful $(147,150)$ and safe (59) measure. This also applies to oncological patients during chemo and radiation therapy (59); ii) in general, the use of single highdose micronutrients should be avoided. An exception is vitamin D. Depending on the basal $25-\mathrm{OH}-\mathrm{D}_{3}$ plasma level, the vitamin D supply should amount to 1800-4000 IU/ day (45-100 $\mu \mathrm{g} /$ day of cholecalciferol) in order to reach the desirable plasma concentration of $>75 \mathrm{nmoll} / \mathrm{l}$ in most oncological patients $(187,188)$; iii) to improve postoperative wound healing, an increased micronutrient supply is recommended [500-2000 $\mathrm{mg}$ /day vitamin C, $3 \mathrm{mg} /$ day vitamin A, $10-15 \mathrm{mg} /$ day vitamin B6, 0.4-1.0 mg/day folic acid, 4-10 mg/day (in case of initially low plasma levels $40 \mathrm{mg} /$ day) zinc, $1-2 \mathrm{mg} /$ day copper] $(163,164)$; and iv) on the basis of a cost-benefit analysis, the tentative adminstration of long-chain $\omega$-3 fatty acids (1.5-2.0 g per day) to patients with weight loss and tumor cachexia is to be recommended (173).

\section{References}

1. Parkin DM, Bray F, Ferlay J and Pisani P: Global cancer statistics, 2002. CA Cancer J Clin 55: 74-108, 2005.

2. Mackay J, Jemal A, Lee N and Parkin DM: The Cancer Atlas. American Cancer Society, 2006.

3. Ströhle A, Wolters M and Hahn A: Nutrition and colorectal cancer. Med Monatsschr Pharm 30: 25-32, 2007.

4. Ströhle A, Wolters M and Hahn A: Folic acid and colorectal cancer prevention: molecular mechanisms and epidemiological evidence (Review). Int J Oncol 26: 1449-1464, 2005.

5. Du YX, Zhou BS and Wu JM: Lifestyle factors and human lung cancer: an overview of recent advances (Review). Int $\mathbf{J}$ Oncol 13: 471-479, 1998.

6. World Cancer Research Fund (WCRF): Food, Nutrition, Physical Activity and the Prevention of Cancer: a Global Perspective. American Institute for Cancer Research, Washington DC, 2007.

7. Platz EA, Willett WC, Colditz GA, Rimm EB, Spiegelman D and Giovannucci E: Proportion of colon cancer risk that might be preventable in a cohort of middle-aged US men. Cancer Causes Control 11: 579-588, 2000.

8. Patel D, Shukla S and Gupta S: Apigenin and cancer chemoprevention: progress, potential and promise (Review). Int J Oncol 30: 233-245, 2007. 
9. Aziz MH, Kumar R and Ahmad N: Cancer chemoprevention by resveratrol: in vitro and in vivo studies and the underlying mechanisms (Review). Int J Oncol 23: 17-28, 2003.

10. Pathak SK, Sharma RA and Mellon JK: Chemoprevention of prostate cancer by diet-derived antioxidant agents and hormonal manipulation (Review). Int J Oncol 22: 5-13, 2003.

11. Zänker KS: Chemoprevention of cancer for the next millenniumquo vadis? Cancer Lett 143 (Suppl. 1): S7-S11, 1999.

12. Van Cutsem E and Arends J: The causes and consequences of cancer-associated malnutrition. Eur J Oncol Nurs 9 (Suppl. 2): S51-S63, 2005.

13. Arends J, Bodoky G, Bozzetti F, Fearon K, Muscaritoli M, Selga G, van Bokhorst-de van der Schueren MA, von Meyenfeldt M; DGEM (German Society for Nutritional Medicine), Zürcher G, Fietkau R, Aulbert E, Frick B, Holm M, Kneba M, Mestrom HJ, Zander A and ESPEN (European Society for Parenteral and Enteral Nutrition): ESPEN Guidelines on Enteral Nutrition: non-surgical oncology. Clin Nutr 25: 245-259, 2006.

14. Marín Caro MM, Laviano A and Pichard C: Impact of nutrition on quality of life during cancer. Curr Opin Clin Nutr Metab Care 10: 480-487, 2007

15. Nitenberg G and Raynard B: Nutritional support of the cancer patient: issues and dilemmas. Crit Rev Oncol Hematol 34: $137-168,2000$

16. Huhmann MB and August DA: Nutrition support in surgical oncology. Nutr Clin Pract 24: 520-526, 2009.

17. Müller MJ and Bosy-Westphal A: Wie beurteile ich den Ernährungszustand bei kranken Menschen? Aktuel Ernährmed 28: 66-71, 2003

18. Pirlich M, Schwenk A and Müller MJ: DGEM Guidelines enteral nutrition: nutritional status. Aktuel Ernähr Med 28 (Suppl. 1): S10-S25, 2003.

19. Bozzetti F and SCRINIO Working Group: Screening the nutritional status in oncology: a preliminary report on 1,000 outpatients. Support Care Cancer 17: 279-284, 2009.

20. Pirlich M, Schutz T, Norman K, et al: The German hospital malnutrition study. Clin Nutr 25: 563-572, 2006.

21. Tong $H$, Isenring $E$ and Yates $P$ : The prevalence of nutrition impact symptoms and their relationship to quality of life and clinical outcomes in medical oncologypatients. Support Care Cancer 17: 83-90, 2009.

22. Gudny Geirsdottir O and Thorsdottir I: Nutritional status of cancer patients in chemotherapy; dietary intake, nitrogen balance and screening. Food Nutr Res 52: 2008.

23. Sorensen J, Kondrup J, Prokopowicz J, Schiesser M, Krähenbühl L, Meier R, Liberda M and EuroOOPS study group: EuroOOPS: an international, multicentre study to implement nutritional risk screening and evaluate clinical outcome. Clin Nutr 27: 340-349, 2008

24. Unsal D, Mentes B, Akmansu M, Uner A, Oguz M and Pak Y: Evaluation of nutritional status in cancer patients receiving radiotherapy: a prospective study. Am J Clin Oncol 29: 183-188, 2006

25. Capuano G, Gentile PC, Bianciardi F, Tosti M, Palladino A and Di Palma M: Prevalence and influence of malnutrition on quality of life and performance status in patients with locally advanced head and neck cancer before treatment. Support Care Cancer 18: 433-437, 2010.

26. Guren MG, Tobiassen LB, Trygg KU, Drevon CA and Dueland S: Dietary intake and nutritional indicators are transiently compromised during radiotherapy for rectal cancer. Eur J Clin Nutr 60: 113-119, 2006

27. Isenring EA, Bauer JD and Capra S: Nutrition support using the American Dietetic Association medical nutrition therapy protocol for radiation oncology patients improves dietary intake compared with standard practice. J Am Diet Assoc 107: 404-412, 2007.

28. Isenring EA, Capra S and Bauer JD: Nutrition intervention is beneficial in oncology outpatients receiving radiotherapy to the gastrointestinal or head and neck area. Br J Cancer 91: 447-452, 2004.

29. Ravasco P, Monteiro-Grillo I, Marques Vidal P and Camilo ME Impact of nutrition on outcome: a prospective randomized controlled trial in patients with head and neck cancer undergoing radiotherapy. Head Neck 27: 659-668, 2005.

30. Ravasco P, Monteiro-Grillo I, Vidal PM and Camilo ME: Dietary counseling improves patient outcomes: a prospective, randomized, controlled trial in colorectal cancer patients undergoing radiotherapy. J Clin Oncol 23: 1431-1438, 2005.

31. Elango N, Samuel S and Chinnakkannu P: Enzymatic and nonenzymatic antioxidant status in stage (III) human oral squamous cell carcinoma and treated with radical radiotherapy: influence of selenium supplementation. Clin Chim Acta 373: 92-98, 2006.
32. Bosaeus I: Nutritional support in multimodal therapy for cancer cachexia. Support Care Cancer 16: 447-451, 2008.

33. Laviano A, Meguid MM, Inui A, Muscaritoli M and Rossi-Fanelli F: Therapy insight: cancer anorexia-cachexia syndrome-when all you can eat is yourself. Nat Clin Pract Oncol 2: 158-165, 2005.

34. Gordon JN, Green SR and Goggin PM: Cancer cachexia. QJM 98: 779-788, 2005

35. Andreyev HJ, Norman AR, Oates J and Cunningham D: Why do patients with weight loss have a worse outcome when undergoing chemotherapy for gastrointestinal malignancies? Eur J Cancer 34: 2132-2133, 1998.

36. Ross PJ, Ashley S, Norton A, Priest K, et al: Do patients with weight loss have a worse outcome when undergoing chemotherapy for lung cancers? Br J Cancer 90: 1905-1911, 2004.

37. Rickard KA, Detamore CM, Coates TD, Grosfeld JL, Weetman RM, White NM, Provisor AJ, Boxer LA, Loghmani ES, Oei TO, Yu PL and Baehner RL: Effect of nutrition staging on treatment delays and outcome in Stage IV neuroblastoma. Cancer 52: 587-598, 1983.

38. Jaakkola K, Lähteenmäki P, Laakso J, Harju E, Tykkä H and Mahlberg K: Treatment with antioxidant and other nutrients in combination with chemotherapy and irradiation in patients with small-cell lung cancer. Anticancer Res 12: 599-606, 1992.

39. Jatoi A, Williams B, Nichols F, Marks R, Aubry MC, Wampfler J, Finke EE and Yang P: Is voluntary vitamin and mineral supplementation associated with better outcome in non-small cell lung cancer patients? Results from the Mayo Clinic lung cancer cohort. Lung Cancer 49: 77-84, 2005.

40. Jatoi A, Williams BA, Marks R, Nichols FC, Aubry MC, Wampfler J and Yang P: Exploring vitamin and mineral supplementation and purported clinical effects in patients with small cell lung cancer: results from the Mayo Clinic lung cancer cohort. Nutr Cancer 51: 7-12, 2005.

41. DeWys WD, Begg C, Lavin PT, Band PR, Bennett JM, Bertino JR, Cohen MH, Douglass HO Jr, Engstrom PF, Ezdinli EZ, Horton J, Johnson GJ, Moertel CG, Oken MM, Perlia C, Rosenbaum C, Silverstein MN, Skeel RT, Sponzo RW and Tormey DC: Prognostic effect of weight loss prior to chemotherapy in cancer patients. Eastern Cooperative Oncology Group. Am J Med 69: 491-497, 1980

42. Van Bokorst-de van der Schueren MAE, van Leeuwen PAM, Kuik DJ, et al: The impact of nutritional status on the prognosis of patients with advanced head and neck cancer. Cancer 86: 519-527, 1999

43. Tian J and Chen JS: Nutritional status and quality of life of the gastric cancer patients in Changle County of China. World J Gastroenterol 11: 1582-1586, 2005.

44. NN: American Institute for Cancer Research: Nutrition of the Cancer Patient. American Institute for Cancer Research, Washington, DC, 2000

45. NN: National Cancer Institute, U.S. National Institutes of Health: Nutrition in cancer care (PDQ). Health Professional Version. http:// www.cancer.gov/cancertopics/pdq/supportivecare/nutrition/Health Professional (Elektronische Publikation, URL am 20.10.2008).

46. Doyle C, Kushi LH, Byers T, Courneya KS, DemarkWahnefried W, Grant B, McTiernan A, Rock CL, Thompson C, Gansler T, Andrews KS; The 2006 Nutrition, Physical Activity and Cancer Survivorship Advisory Committee; American Cancer Society: Nutrition and physical activity during and after cancer treatment: an American Cancer Society guide for informed choices. CA Cancer J Clin 56: 323-353, 2006.

47. Gogos CA, Ginopoulos P, Salsa B, Apostolidou E, Zoumbos NC and Kalfarentzos F: Dietary omega-3 polyunsaturated fatty acids plus vitamin $\mathrm{E}$ restore immunodeficiency and prolong survival for severely ill patients with generalized malignancy: a randomized control trial. Cancer 82: 395-402, 1998 .

48. Wigmore SJ, Barber MD, Ross JA, Tisdale MJ and Fearon KC: Effect of oraleicosapentaenoic acid on weight loss in patients with pancreatic cancer. Nutr Cancer 36: 177-184, 2000.

49. Wigmore SJ, Ross JA, Falconer JS, Plester CE, Tisdale MJ, Carter DC and Fearon KC: The effect of polyunsaturated fatty acids on the progress of cachexia in patients with pancreatic cancer. Nutrition 12 (Suppl. 1): S27-S30, 1996.

50. Biondo PD, Brindley DN, Sawyer MB and Field CJ: The potential for treatment with dietary long-chain polyunsaturated n-3 fatty acids during chemotherapy. J Nutr Biochem 19: 787-796, 2008.

51. Federico A, Iodice P, Federico P, Del Rio A, Mellone MC, Catalano $G$ and Federico P: Effects of selenium and zinc supplementation on nutritional status in patients with cancer of digestive tract. Eur J Clin Nutr 55: 293-297, 2001. 
52. Mantovani G, Macciò A, Madeddu C, Mura L, Gramignano G, Lusso MR, Massa E, Mocci M and Serpe R: Antioxidant agents are effective in inducing lymphocyte progression through cell cycle in advanced cancer patients: assessment of the most important laboratory indexes of cachexia and oxidative stress. J Mol Med 81: 664-673, 2003.

53. Mantovani G, Macciò A, Madeddu C, Mura L, Gramignano G, Lusso MR, Murgia V, Camboni P, Ferreli L, Mocci M and Massa E: The impact of different antioxidant agents alone or in combination on reactive oxygen species, antioxidant enzymes and cytokines in a series of advanced cancer patients at different sites: correlation with disease progression. Free Radic Res 37: 213-223, 2003.

54. Mantovani G, Macciò A, Madeddu C, Gramignano G, Lusso MR, Serpe R, Massa E, Astara G and Deiana L: A phase II study with antioxidants, both in the diet and supplemented, pharmaconutritional support, progestagen, and anti-cyclooxygenase- 2 showing efficacy and safety in patients with cancer-related anorexia/ cachexia and oxidative stress. Cancer Epidemiol Biomarkers Prev 15: 1030-1034, 2006

55. Marín Caro MM, Laviano A and Pichard C: Nutritional intervention and quality of life in adult oncology patients. Clin Nutr 26: 289-301, 2007.

56. Mantovani G, Macciò A, Madeddu C, Gramignano G, Serpe R, Massa E, Dessì M, Tanca FM, Sanna E, Deiana L, Panzone F, Contu P and Floris C: Randomized phase III clinical trial of five different arms of treatment for patients with cancer cachexia: interim results. Nutrition 24: 305-313, 2008.

57. Block KI, Koch AC, Mead MN, Tothy PK, Newman RA and Gyllenhaal C: Impact of antioxidant supplementation on chemotherapeutic efficacy: a systematic review of the evidence from randomized controlled trials. Cancer Treat Rev 33: 407-418, 2007.

58. Block KI, Koch AC, Mead MN, Tothy PK, Newman RA and Gyllenhaal C: Impact of antioxidant supplementation on chemotherapeutic toxicity: a systematic review of the evidence from randomized controlled trials. Int J Cancer 123: 1227-1239, 2008 .

59. Norman HA, Butrum RR, Feldman E, Heber D, Nixon D, Picciano MF, Rivlin R, Simopoulos A, Wargovich MJ, Weisburger EK and Zeisel SH: The role of dietary supplements during cancer therapy. J Nutr 133 (Suppl. 11): S3794-S3799, 2003.

60. Prasad KN, Kumar A, Kochupillai V and Cole WC: High doses of multiple antioxidant vitamins: essential ingredients in improving the efficacy of standard cancer therapy. J Am Coll Nutr 18: 13-25, 1999

61. Prasad KN, Cole WC, Kumar B and Prasad KC: Scientific rationale for using high-dose multiple micronutrients as an adjunct to standard and experimental cancer therapies. J Am Coll Nutr 20 (Suppl. 5): S450-S463, 2001

62. Prasad KN, Cole WC, Kumar B and Che Prasad K: Pros and cons of antioxidant use during radiation therapy. Cancer Treat Rev 28: 79-91, 2002

63. Prasad KN: Antioxidants in cancer care: when and how to use them as an adjunct to standard and experimental therapies. Expert Rev Anticancer Ther 3: 903-915, 2003.

64. Prasad KN: Multiple dietary antioxidants enhance the efficacy of standard and experimental cancer therapies and decrease their toxicity. Integr Cancer Ther 3: 310-322, 2004.

65. D'Andrea GM: Use of antioxidants during chemotherapy and radiotherapy should be avoided. CA Cancer J Clin 55: 319-321, 2005 .

66. Lawenda BD, Kelly KM, Ladas EJ, Sagar SM, Vickers A and Blumberg JB: Should supplemental antioxidant administration be avoided during chemotherapy and radiation therapy? J Natl Cancer Inst 100: 773-783, 2008

67. Van Ommen B, Fairweather-Tait S, Freidig A, Kardinaal A, Scalbert A and Wopereis S: A network biology model of micronutrient related health. Br J Nutr 99 (Suppl. 3): S72-S80, 2008.

68. Laviano A and Meguid MM: Nutritional issues in cancer management. Nutrition 12: 358-371, 1996.

69. DeWys WD: Anorexia as a general effect of cancer. Cancer 43 (Suppl. 5): 2013-2019, 1979.

70. Ravasco P: Aspects of taste and compliance in patients with cancer. Eur J Oncol Nurs 9 (Suppl. 2): S84-S91, 2005.

71. Hutton JL, Baracos VE and Wismer WV: Chemosensory dysfunction is a primary factor in the evolution of declining nutritional status and quality of life in patients with advanced cancer. J Pain Symptom Manage 33: 156-165, 2007.
72. Brisbois TD, Hutton JL, Baracos VE and Wismer WV: Taste and smell abnormalities as an independent cause of failure of food intake in patients with advanced cancer, an argument for the application of sensory science. J Palliat Care 22: 111-114, 2006.

73. Khalid U, Spiro A, Baldwin C, Sharma B, McGough C, Norman AR, Eisen T, O'Brien ME, Cunningham D and Andreyev HJ: Symptoms and weight loss in patients with gastrointestinal and lung cancer at presentation. Support Care Cancer 15: 39-46, 2007

74. Lesko LM: Psychosocial issues in the diagnosis and management of cancer cachexia and anorexia. Nutrition 5: 114-116, 1989.

75. Laviano A, Meguid MM and Rossi-Fanelli F: Cancer anorexia: clinical implications, pathogenesis, and therapeutic strategies. Lancet Oncol 4: 686-694, 2003.

76. Perboni S and Inui A: Anorexia in cancer: role of feedingregulatory peptides. Philos Trans R Soc Lond B Biol Sci 361: 1281-1289, 2006.

77. Ramos EJ, Suzuki S, Marks D, Inui A, Asakawa A and Meguid MM: Cancer anorexia-cachexia syndrome: cytokines and neuropeptides. Curr Opin Clin Nutr Metab Care 7: 427-434, 2004.

78. Zürcher G: Anorectic syndrome. Z Gastroenterol 40 (Suppl. 1): S71-S75, 2002

79. Dische S, Warburton MF, Jones D and Lartigau E: The recording of morbidity related to radiotherapy. Radiother Oncol 16: 103-108, 1989

80. Dische S, Vaeth JM and Meyer JL: Conference summary. Radiation tolerance of normal tissues. Front Radiat Ther Oncol 16: 419-427, 1989

81. Donaldson SS: Nutritional consequences of radiotherapy. Cancer Res 37: 2407-2413, 1977.

82. Chencharick JD and Mossman KL: Nutritional consequences of the radiotherapy of head and neck cancer. Cancer 51: 811-815, 1983

83. Mahdavi R, Faramarzi E, Mohammad-Zadeh M, Ghaeammaghami J and Jabbari MV: Consequences of radiotherapy on nutritional status, dietary intake, serum zinc and copper levels in patients with gastrointestinal tract and head and neck cancer. Saudi Med J 28: 435-440, 2007.

84. Grant M and Kravits K: Symptoms and their impact on nutrition. Semin Oncol Nurs 16: 113-121, 2000.

85. O'Brien BE, Kaklamani VG and Benson AB III: The assessment and management of cancer treatment-related diarrhea. Clin Colorectal Cancer 4: 375-381, 2005.

86. Naidu MU, Ramana GV, Rani PU, Mohan IK, Suman A and Roy P: Chemotherapy-induced and/or radiation therapy-induced oral mucositis, complicating the treatment of cancer. Neoplasia 6: 423-431, 2004

87. Donaldson SS: Nutritional support as an adjunct to radiation therapy. JPEN J Parenter Enteral Nutr 8: 302-310, 1984.

88. Baracos VE: Cancer-associated cachexia and underlying biological mechanisms. Annu Rev Nutr 26: 435-461, 2006.

89. Tisdale MJ: Mechanisms of cancer cachexia. Physiol Rev 89: 381-410, 2009

90. Tisdale MJ: The ubiquitin-proteasome pathway as a therapeutic target for muscle wasting. J Support Oncol 3: 209-217, 2005.

91. Tisdale MJ: Cachexia in cancer patients. Nat Rev Cancer 2: 862-871, 2002

92. Argilés JM, Busquets S and López-Soriano FJ: Cytokines in the pathogenesis of cancer cachexia. Curr Opin Clin Nutr Metab Care 6: 401-406, 2003.

93. Norton JA, Stein TP and Brennan MF: Whole body protein synthesis and turnover in normal man and malnourished patients with and without known cancer. Ann Surg 194: 123-128, 1981.

94. Lundholm K, Edström S, Ekman L, Karlberg I and Scherstén T: Metabolism in peripheral tissues in cancer patients. Cancer Treat Rep 65 (Suppl. 5): S79-S83, 1981

95. Smith HJ, Wyke SM and Tisdale MJ: Role of protein kinase C and NF-kappaB in proteolysis-inducing factor-induced proteasome expression in $\mathrm{C}(2) \mathrm{C}(12)$ myotubes. Br J Cancer 90: 1850-1857, 2004.

96. Whitehouse AS and Tisdale MJ: Increased expression of the ubiquitin-proteasome pathway in murine myotubes by proteolysis-inducing factor (PIF) is associated with activation of the transcription factor NF-kappaB. Br J Cancer 89: 1116-1122, 2003.

97. Wyke SM, Khal J and Tisdale MJ: Signalling pathways in the induction of proteasome expression by proteolysis-inducing factor in murine myotubes. Cell Signal 17: 67-75, 2005. 
98. Wyke SM and Tisdale MJ: NF-kappaB mediates proteolysisinducing factor induced protein degradation and expression of the ubiquitin-proteasome system in skeletal muscle. $\mathrm{Br} \mathrm{J}$ Cancer 92: 711-721, 2005.

99.Fouladiun M, Körner U, Bosaeus I, Daneryd P, Hyltander A and Lundholm KG: Body composition and time course changes in regional distribution of fat and lean tissue in unselected cancer patients on palliative care, correlations with food intake, metabolism, exercise capacity, and hormones. Cancer 103: 2189-2198, 2005

100.Shaw JH and Wolfe RR: Fatty acid and glycerol kinetics in septic patients and in patients with gastrointestinal cancer. The response to glucose infusion and parenteral feeding. Ann Surg 205: 368-376, 1987.

101. Legaspi A, Jeevanandam M, Starnes HF Jr and Brennan MF: Whole body lipid and energy metabolism in the cancer patient. Metabolism 36: 958-963, 1987.

102. Russell ST and Tisdale MJ: The role of glucocorticoids in the induction of zinc-alpha2-glycoprotein expression in adipose tissue in cancer cachexia. Br J Cancer 92: 876-881, 2005.

103. Hirai K, Hussey HJ, Barber MD, Price SA and Tisdale MJ: Biological evaluation of a lipid-mobilizing factor isolated from the urine of cancer patients. Cancer Res 58: 2359-2365, 1998.

104. Fearon KC, Voss AC, Hustead DS and Cancer Cachexia Study Group: Definition of cancer cachexia: effect of weight loss, reduced food intake, and systemic inflammation on functional status and prognosis. Am J Clin Nutr 83: 1345-1350, 2006.

105. Uomo G, Gallucci F and Rabitti PG: Anorexia-cachexia syndrome in pancreatic cancer: recent development in research and management. JOP 7: 157-162, 2006.

106. Barber MD, Ross JA and Fearon KC: Disordered metabolic response with cancer and its management. World J Surg 24: 681-689, 2000.

107. Argilés JM, Costelli P, Carbó N, Pallarés-Trujillo J and LópezSoriano FJ: Tumour growth and nitrogen metabolism in the host (Review). Int J Oncol 14: 479-486, 1999.

108. Tubiana M, Attié E, Flamant R, et al: Prognostic factors in 454 cases of Hodgkin's disease. Cancer Res 31: 1801-1810, 1971.

109. Swenerton KD, Legha SS, Smith T, et al: Prognostic factors in metastaticbreast cancer treated with combination chemotherapy. Cancer Res 39: 1552-1562, 1979.

110. Persson $\mathrm{C}$ and Glimelius B: The relevance of weight loss for survival and quality of life in patients with advanced gastrointestinal cancer treated with palliative chemotherapy. Anticancer Res 22: 3661-3668, 2002.

111. Stanley K: Prognostic factors for survival in patients with inoperable lung cancer. J Natl Cancer Inst 65: 25-32, 1980.

112. Pedersen H, Hansen HS, Cederqvist $\mathrm{C}$ and Lober J: The prognostic significance of weight loss and its integration in stage-grouping of oesophageal cancer. Acta Chir Scand 148 363-366, 1982 .

113. Fein R, Kelsen DP, Geller N, et al: Adenocarcinoma of the esophagus and gastroesophageal junction. Prognostic factors and results of therapy. Cancer 15: 2512-2518, 1985.

114. Edington J, Winter PD, Cole SJ, et al: Outcomes of undernutrition in the community with cancer or cardiovascular disease. Proc Nutr Soc 58: 655-661, 1999.

115. Bosaeus I, Daneryd P and Lundholm K: Dietary intake, resting energy expenditure, weight loss and survival in cancer patients. J Nutr 132: S3465-S3466, 2002.

116. Bosaeus IG, Ellegard L, Malmros V, et al: Body composition, gender, and survival in advanced cancer. Clin Nutr (Suppl. 2): $111,2007$.

117. Gupta D, Lammersfeld CA, Burrows JL, et al: Bioelectric impedance phase angle in clinical practice: implications for prognosis in advanced colorectal cancer. Am J Clin Nutr 80: 1634-1638, 2004

118. Mitry E, Douillard JY, Van Cutsem E, et al: Predictive factors of survival in patients with advanced colorectal cancer: an individual data analysis of 602 patients included in irinotecan phase III trials. Ann Oncol 15: 1013-1017, 2004.

119. Lee GJ, Chung HW, Lee KH and Ahn HS: Antioxidant vitamins and lipid peroxidation in patients with cervical intraepithelial neoplasia. J Korean Med Sci 20: 267-272, 2005.

120.Skrzydlewska E, Sulkowski S, Koda M, Zalewski B, Kanczuga-Koda L and Sulkowska M: Lipid peroxidation and antioxidant status in colorectal cancer. World J Gastroenterol 11: 403-406, 2005.
121. Yeh CC, Hou MF, Tsai SM, Lin SK, Hsiao JK, Huang JC, Wang LH, Wu SH, Hou LA, Ma H and Tsai LY: Superoxide anion radical, lipid peroxides and antioxidant status in the blood of patients with breast cancer. Clin Chim Acta 361: 104-111, 2005.

122. Trump DL, Chadha MK, Sunga AY, Fakih MG, Ashraf U, Silliman CG, Hollis BW, Nesline MK, Tian L, Tan W and Johnson CS: Vitamin D deficiency and insufficiency among patients with prostate cancer. BJU Int, April 4, 2009. (Epub ahead of print).

123. Fakih MG, Trump DL, Johnson CS, Tian L, Muindi J and Sunga AY: Chemotherapy is linked to severe vitamin D deficiency in patients with colorectal cancer. Int J Colorectal Dis 24: 219-224, 2009

124. Crew KD, Shane E, Cremers S, McMahon DJ, Irani D and Hershman DL: High prevalence of vitamin D deficiency despite supplementation in premenopausal women with breast cancer undergoing adjuvant chemotherapy. J Clin Oncol 27: 2151-2156, 2009.

125. Palan PR, Woodall AL, Anderson PS and Mikhail MS: Alphatocopherol and alpha-tocopheryl quinone levels in cervical intraepithelial neoplasia and cervical cancer. Am J Obstet Gynecol 190: 1407-1410, 2004.

126. Ray G and Husain SA: Role of lipids, lipoproteins and vitamins in women with breast cancer. Clin Biochem 34: 71-76, 2001.

127.Lin CC and Yin MC: B vitamins deficiency and decreased anti-oxidative state in patients with liver cancer. Eur J Nutr 46: 293-299, 2007.

128. Tsao SM, Yin MC and Liu WH: Oxidant stress and B vitamins status in patients with non-small cell lung cancer. Nutr Cancer 59: 8-13, 2007.

129. Anthony HM and Schorah CJ: Severe hypovitaminosis C in lung-cancer patients: the utilization of vitamin $\mathrm{C}$ in surgical repair and lymphocyte-related host resistance. Br J Cancer 46: 354-367, 1982.

130. Fin O, Mathieu E and Thomas M: Scurvy in patients with cancer. BMJ 316: 1661-1662, 1998.

131.Zuo XL, Chen JM, Zhou X, Li XZ and Mei GY: Levels of selenium, zinc, copper, and antioxidant enzyme activity in patients with leukemia. Biol Trace Elem Res 114: 41-53, 2006.

132. Büntzel J, Bruns F, Glatzel M, Garayev A, Mücke R, Kisters K, Schäfer U, Schönekaes $\mathrm{K}$ and Micke O: Zinc concentrations in serum during head and neck cancer progression. Anticancer Res 27: 1941-1943, 2007.

133. Stefanini M: Cutaneous bleeding related to zinc deficiency in two cases of advanced cancer. Cancer 86: 866-870, 1999.

134. Mantovani G, Macciò A, Madeddu C, Mura L, Massa E, Gramignano G, Lusso MR, Murgia V, Camboni P and Ferreli L: Reactive oxygen species, antioxidant mechanisms and serum cytokine levels in cancer patients: impact of an antioxidant treatment. J Cell Mol Med 6: 570-582, 2002.

135. Chang D, Wang F, Zhao YS and Pan HZ: Evaluation of oxidative stress in colorectal cancer patients. Biomed Environ Sci 21: 286-289, 2008.

136. Leung EY, Crozier JE, Talwar D, O'Reilly DS, McKee RF, Horgan PG and McMillan DC: Vitamin antioxidants, lipid peroxidation, tumour stage, the systemic inflammatory response and survival in patients with colorectal cancer. Int J Cancer 123: 2460-2464, 2008.

137. Clemens MR, Müller-Ladner CI and Gey KF: Vitamins during high dose chemo- and radiotherapy. Z Ernährungswiss 31: 110-120, 1992.

138. Clemens MR, Ladner C, Ehninger G, Einsele H, Renn W, Bühler E, Waller HD and Gey KF: Plasma vitamin E and betacarotene concentrations during radiochemotherapy preceding bone marrow transplantation. Am J Clin Nutr 51: 216-219, 1990.

139.Kennedy DD, Ladas EJ, Rheingold SR, Blumberg J and Kelly KM: Antioxidant status decreases in children with acute lymphoblastic leukemia during the first six months of chemotherapy treatment. Pediatr Blood Cancer 44: 378-385, 2005.

140. Malvy DJ, Burtschy B, Arnaud J, Sommelet D, Leverger G, Dostalova L, Drucker J and Amédée-Manesme O: Serum beta-carotene and antioxidant micronutrients in children with cancer. The 'Cancer in Children and Antioxidant Micronutrients' French Study Group. Int J Epidemiol 22: 761-771, 1993.

141.Lotti T, Rodofili C, Benci M and Menchin G: Wound-healing problems associated with cancers. J Wound Care 7: 81-84, 1998. 
142.Dormand EL, Banwell PE and Goodacre TE: Radiotherapy and wound healing. Int Wound J 2: 112-127, 2005.

143. Bryan J and Calvaresi E: Associations between dietary intake of folate and vitamins B-12 and B-6 and self-reported cognitive function and psychological well-being in Australian men and women in midlife. J Nutr Health Aging 8: 226-232, 2004

144. Kamphuis MH, Geerlings MI, Grobbee DE and Kromhout D Dietary intake of B(6-9-12) vitamins, serum homocysteine levels and their association with depressive symptoms: the Zutphen Elderly Study. Eur J Clin Nutr 62: 939-945, 2008.

145. Ströhle A and Hahn A: Vitamin C and immune function. Med Monatsschr Pharm 32: 49-54, 2009.

146. Ströhle A and Hahn A: Bedeutung von Mikronährstoffen für die Immunkomeptenz. Präventive und therapeutische Aspekte. MMW Fortschr Med Originalien III: 133-141, 2009.

147. Biesalski H-K: Mikronährstoffsupplemente bei onkologischen Patienten. Onkologe 14: 45-57, 2008.

148.Hahn A, Ströhle A and Biesalski HK: Mikronährstoff-supplemente. In: Ernährungsmedizin. Biesalski HK, Bischoff S and Puchstein S (eds). Thieme, Stuttgart, 2010.

149. Hutton JL, Martin L, Field CJ, Wismer WV, Bruera ED, Watanabe SM and Baracos VE: Dietary patterns in patients with advanced cancer: implications for anorexia-cachexia therapy. Am J Clin Nutr 84: 1163-1170, 2006

150.Zürcher G, Gola U and Biesalski H-K: Antioxidanzien bei Krebs. Schweizer Zeitschrift für Ernährungsmedizin 4: 17-19, 2007

151. Labriola D and Livingston R: Possible interactions between dietary antioxidants and chemotherapy. Oncology 13: 1003$1008,1999$.

152. Salganik RI, Albright CD, Rodgers J, Kim J, Zeisel SH, Sivashinskiy MS and Van Dyke TA: Dietary antioxidant depletion: enhancement of tumor apoptosis and inhibition of brain tumor growth in transgenic mice. Carcinogenesis 21 : 909-914, 2000.

153. Kucuk O and Ottery FD: Dietary supplements during cancer treatment. Oncol Issues 17: 22-30, 2002.

154. Michaud LB, Karpinski JP, Jones KL and Espirito J: Dietary supplements in patients with cancer: risks and key concepts, part 2. Am J Health Syst Pharm 64: 467-480, 2007.

155. Michaud LB, Karpinski JP, Jones KL and Espirito J: Dietary supplements in patients with cancer: risks and key concepts, part 1. Am J Health Syst Pharm 64: 369-381, 2007.

156. Simone CB II, Simone NL, Simone V and Simone CB: Antioxidants and other nutrients do not interfere with chemotherapy or radiation therapy and can increase kill and increase survival, part 1. Altern Ther Health Med 13: 22-28, 2007.

157. Simone CB II, Simone NL, Simone V and Simone CB Antioxidants and other nutrients do not interfere with chemotherapy or radiation therapy and can increase kill and increase survival, Part 2. Altern Ther Health Med 13: 40-47, 2007.

158. Greenlee H, Hershman DL and Jacobson JS: Use of antioxidant supplements during breast cancer treatment: a comprehensive review. Breast Cancer Res Treat 115: 437-452, 2009.

159. Hardy ML: Dietary supplement use in cancer care: help or harm. Hematol Oncol Clin North Am 22: 581-617, 2008.

160. Brown JK, Byers T, Doyle C, Coumeya KS, DemarkWahnefried W, Kushi LH, McTieman A, Rock CL, Aziz N, Bloch AS, Eldridge B, Hamilton K, Katzin C, Koonce A, Main J, Mobley C, Morra ME, Pierce MS, Sawyer KA and American Cancer Society: Nutrition and physical activity during and after cancer treatment: an American Cancer Society guide for informed choices. CA Cancer J Clin 53: 268-291, 2003.

161.Gross RL: The effect of ascorbate on wound healing. Int Ophthalmol Clin 40: 51-57, 2000.

162. Borkow G, Gabbay J and Zatcoff RC: Could chronic wounds not heal due to too low local copper levels? Med Hypotheses 70: 610-613, 2008.

163. Demling RH: Nutrition, anabolism, and the wound healing process: an overview. Eplasty 9: e9, 2009

164. Kurrmann S and Burrowes JD: Nutrition of non-critically ill wound patients, special supplements. Aktuel Ernährungsmed 34: 269-277, 2009.

165. Hausinnger RP: Fell/alpha-ketoglutarate-dependent hydroxylases and related enzymes. Crit Rev Biochem Mol Biol 39: 21-68, 2004.

166.Padh H: Cellular functions of ascorbic acid. Biochem Cell Biol 68: 1166-1173, 1990

167. Shukla SP: Plasma and urinary ascorbic acid levels in the postoperative period. Experientia 25: 704, 1969.
168. Irvin TT, Chattopadhyay DK and Smythe A: Ascorbic acid requirements in postoperative patients. Surg Gynecol Obstet 147: 49-55, 1978 .

169. Taylor TV, Rimmer S, Day B, Butcher J and Dymock IW: Ascorbic acid supplementation in the treatment of pressuresores. Lancet 2: 544-546, 1974

170.Mantovani G, Madeddu C, Macciò A, Gramignano G, Lusso MR, Massa E, Astara G and Serpe R: Cancer-related anorexia/cachexia syndrome and oxidative stress: an innovative approach beyond current treatment. Cancer Epidemiol Biomarkers Prev 13: 1651-1659, 2004.

171.Laviano A, Meguid MM, Preziosa I and Rossi Fanelli F: Oxidative stress and wasting in cancer. Curr Opin Clin Nutr Metab Care 10: 449-456, 2007.

172. Bonetto A, Penna F, Muscaritoli M, Minero VG, Rossi Fanelli F, Baccino FM and Costelli P: Are antioxidants useful for treating skeletal muscle atrophy? Free Radic Biol Med 47: 906-916, 2009.

173.Colomer R, Moreno-Nogueira JM, García-Luna PP, García-Peris P, García-de-Lorenzo A, Zarazaga A, Quecedo L, del Llano J, Usán L and Casimiro C: N-3 fatty acids, cancer and cachexia: a systematic review of the literature. $\mathrm{Br} \mathrm{J}$ Nutr 97: 823-831, 2007.

174. Elia M, Van Bokhorst-de van der Schueren MA, Garvey J, Goedhart A, Lundholm K, Nitenberg G and Stratton RJ: Enteral (oral or tube administration) nutritional support and eicosapentaenoic acid in patients with cancer: a systematic review. Int J Oncol 28: 5-23, 2006.

175. Muscaritoli M, Costelli P, Aversa Z, Bonetto A, Baccino FM and Rossi Fanelli F: New strategies to overcome cancer cachexia: from molecular mechanisms to the 'Parallel Pathway'. Asia Pac J Clin Nutr 17 (Suppl. 1): 387-390, 2008

176. Sinclair HM: Essential fatty acids: an historical perspective. Biochem Soc Trans 18: 756-761, 1990.

177. Pawlosky RJ, Hibbeln JR, Novotny JA, et al: Physiological compartmental analysis of alpha-linolenic acid metabolism in adult humans. J Lipid Res 42: 1257-1265, 2001.

178. Brenna JT: Efficiency of conversion of alpha-linolenic acid to long chain n-3 fatty acids in man. Curr Opin Clin Nutr Metab Care 5: 127-132, 2002

179. Wallis JG, Watts JL and Browse J: Polyunsaturated fatty acid synthesis: what will they think of next? Trends Biochem Sci 27: 467, 2002

180. Stehr SN and Heller AR: Omega-3 fatty acid effects on biochemical indices following cancer surgery. Clin Chim Acta 373: 1-8, 2006

181.Li YP and Reid MB: NF-kappaB mediates the protein loss induced by TNF-alpha in differentiated skeletal muscle myotubes. Am J Physiol Regul Integr Comp Physiol 279: R1165-R1170, 2000

182. Goodwin PJ, Ennis M, Pritchard KI, Koo J and Hood N: Prognostic effects of 25-hydroxyvitamin D levels in early breast cancer. J Clin Oncol 27: 3757-3763, 2009.

183.Ng K, Wolpin BM, Meyerhardt JA, Wu K, Chan AT, Hollis BW, Giovannucci EL, Stampfer MJ, Willett WC and Fuchs CS: Prospective study of predictors of vitamin D status and survival in patients with colorectal cancer. Br J Cancer 101: 916-923, 2009.

184.Ng K, Meyerhardt JA, Wu K, Feskanich D, Hollis BW, Giovannucci EL and Fuchs CS: Circulating 25-hydroxyvitamin D levels and survival in patients with colorectal cancer. J Clin Oncol 26: 2984-2991, 2008.

185. Molassiotis A, Fernandez-Ortega P, Pud D, Ozden G, Platin N, Hummerston S, Scott JA, Panteli V, Gudmundsdottir G, Selvekerova S, Patiraki E and Kearney N: Complementary and alternative medicine use in colorectal cancer patients in seven European countries. Complement Ther Med 13: 251-257, 2005.

186. Molassiotis A, Fernadez-Ortega P, Pud D, Ozden G, Scott JA, Panteli V, Margulies A, Browall M, Magri M, Selvekerova S, Madsen E, Milovics L, Bruyns I, Gudmundsdottir G, Hummerston S, Ahmad AM, Platin N, Kearney N and Patiraki E: Use of complementary and alternative medicine in cancer patients: a European survey. Ann Oncol 16: 655-663, 2005.

187. Bischoff-Ferrari HA, Shao A, Dawson-Hughes B, Hathcock J, Giovannucci E and Willett WC: Benefit-risk assessment of vitamin D supplementation. Osteoporos Int, December 3, 2009 (Epub ahead of print).

188. Cantor I: Shedding light on vitamin D and integrative oncology. Integr Cancer Ther 7: 81-89, 2008. 